\title{
MR. JUSTICE HOLMES' VIEW OF LEGAI SCIENCE
}

\author{
HESSEL E. YNTEMA
}

IT is to be doubted whether legal science owes more to $\mathrm{Mr}$. Justice Holmes than it does to the uncommon scholar who fifty years ago lectured on The Common Law.1 Both scholar and judge have the same marks of genius: nowhere a clearer, more prophetic vision of the realities of law; nowhere a more poetic power to clothe living thought in vivid, enduring vesture. Yet the judge could scarce have been without the scholar; his greatness is the scholar's. And the scholar's medium is more revenling, less transient, than that of the judge. It does not break into fragmentary episodes which tend to fuse into the majestic but shifting mosaic of the law; it reaches to a higher and more impressionable intellectual level than that addressed by the judicial opinion; it has greater projection in time and space. Nevertheless, it were ungracious to regret that the scholar became the judge, for, before doing so, he gave us the one outstanding, American work on the history of the Common Law and has at times returned to write the judge's papers and the more important of his addresses. The significance of this scholarly work is out of all proportion to its bulk, principally because it suggests a philosophy of law which has been a precious gift of prophecy to legal science.

No one can speak for another, certainly not for him whose words are beyond paraphrase. Without endeavoring to do so, perhaps one who can scarce claim to have been touched by Holmes' mantle, who owes more immediate debts to such diverse creditors as Bentham, Althusius and Maine, Vinogradoff and Munroe Smith, may appropriately sketch an interpretation of Holmes' view of legal science. At the least, his admiration and belief that this view still awaits realization will not be charged to familiar prejudice.

In Holmes' view of legal science, there are three chief elements which it is instructive to distinguish-the theory of legal history, the canons of dogmatic study, and the rational or scientific ideal. These elements, not unrelated, are differentiated in the major addresses, The Path of the Law: (1897) and Law in Science and Science in $\operatorname{Law}^{3}$ (1899). Roughly speaking, the basic structure is the theory of legal history as outlined in the first lecture on The Common Law; ${ }^{4}$ this, enriched by judicial

1 Holmes, The Common LaW (1881).

2 Holnies, Collected Legal Papers (1921) 167.

3 Ioid. 210.

\& Holmes, The Common LaW (1881) 1. 
experience and projected upon contemporary legal study, becomes the canons of dogmatic study in The Path of the Law. The rational or scientific ideal, envisaged in the two addresses mentioned, is the conclusion of the argument. We shall first endeavor to formulate, perforce with all the imperfection of ibrevity, the cardinal implications of the theory, the canons and the ideal, and then venture a summary glance at their validity, limits and present pertinence.

First, then, as to the theory of legal history. "Historical explanation has two directions or aspects, one practical and the other abstractly scientific." s The latter involves the study of law as "a great anthropological document," or as "an exercise in the morphology and transformation of human ideas." " The emphasis is, however, upon the practical aspects of historical study: "The main ends of the subject are practical." " "History is the means by which we measure the power which the past has had to govern the present in spite of ourselves, so to speak, by imposing traditions which no longer meet their original end. History sets us free and enables us to make up our minds dispassionately whether the survival which we are enforcing answers any new purpose when it has ceased to answer the old." $s$ This is a vigorous conception of historical study, which has little sympathy for mere antiquarianism: investigation directed "to a crucial point" counts; "our only interest in the past is for the light it throws upon the present." 10

The study of the present by reference to the past, the possibilities of which are so brilliantly illustrated in The Common Law, necessarily invites a theory of legal evolution. The fundamental hypothesis is the paradox of form and substance in law:

"The substance of the law at any given time pretty nearly corresponds, so far as it goes, with what is then understood to be convenient; but its form and machinery, and the degree to which it is able to work out desired results, depend very much upon its past." 11

This hypothesis, simple, subtle and profound, is the cornerstone of Holmes' view of legal science as well as of his theory of legal history.

5 Holmes, Colilected Legal Papers (1921) 211.

Ibid. 212.

TIbid. 224.

8 Ibid. 225.

9 "The man of science in the law is not merely a bookworm. To a microscopic eye for detail he must unite an insight which tells him what details are significant. Not every maker of exact investigation counts, but only he who directs his investigation to a crucial point." Ibid. 224.

10 Ibid. 194.

11 Holmes, The Common Law (1881) 1-2. 
The implications which the hypothesis holds for legal history were explicitly set out in 1881 . These may be summarized as follows. First, an empirical conception of law. "Law, being a practical thing, must found itself on actual forces." ${ }^{2}$ Second, that "in substance the growth of the law is legislative," 13 not only in content but in its grounds. Hence the importance of "the felt necessities of the time, the prevalent moral and political theories, intuitions of public policy, avowed or unconscious, even the prejudices which judges share with their fellow-men," ${ }^{14}$ in the interpretation and adaptation of ancient rules or the crention of new. Third, the secondary significance of logical forms. and the consequent "failure of all theories which consider" the law only from its formal side." 15 "The life of the law has not been logic: it has been experience." 16 Fourth, the existence of primitive survivals in law, which render historical study necessary to understand a legal system purporting to follow precedents, ${ }^{17}$ - survivals, the justification for which when identified by historical study, may effectively be reconsidered. ${ }^{18}$ Finally, the desirability of an actualistic description of the process, involving not only "a more conscious recognition of the legislative function of the courts" but also the progressive measurement of human conduct by more "external or objective" and less moral, legal standards. ${ }^{30}$

Second, the canons of dogmatic study. These, as has been intimated, are in effect the application of the theory of legal history to contemporary professional legal study. And, as might be anticipated, the propositions are analogous. In the first place, the conception of the "body of dogma or systematized prediction which we call the law," ${ }^{20}$ is practical, realistic. "The object of our study, then, is prediction, the prediction of the incidence of the public force through the instrumentality of the courts." 21

In the second place, the conception is objective. The study is "of the law as a business with well understood limits, a body of dogma within definite lines." ${ }_{22}$ Hence, to avoid confusion, the necessity of distinction between law and ethics, of a "bad man" attitude towards law:

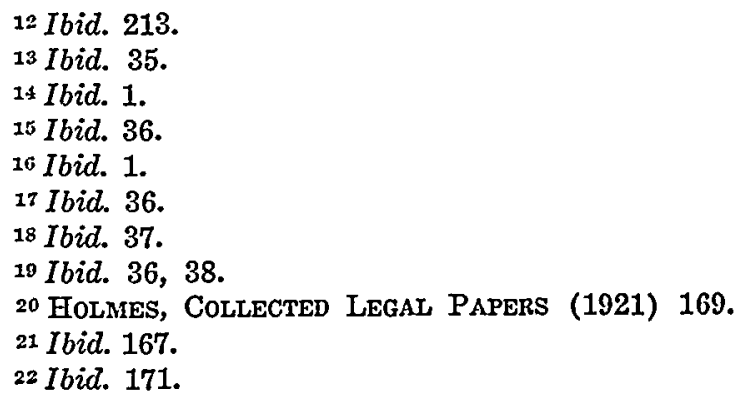


"If you want to know the law and nothing else, you must look at it as a bad man, who cares only for the material consequences which such knowledge enables him to predict, not as a good one, who finds his reasons for conduct, whether inside the law or outside of it, in the vaguer sanctions of conscience." 23

It should be noted that this canon of professional study does not deny ethies or its fundamental relation to law. "The law is the witness and external deposit of our moral life." 21

In the third place, the means of prediction are, in principle, the reports. The reports are "the oracles of the law. Far the most important and pretty nearly the whole meaning of every new effort of legal thought is to make these prophecies more precise, and to generalize them into a thoroughly connected system." "The number of our predictions when generalized and reduced to a system is not unmanageably large." 20 In this Holmes is essentially in accord with Langdell.

In the fourth place, the necessity of analysis and generalization in prediction fixes the position of jurisprudence and theory in dogmatic study. "Theory is the most important part of the dogma of the law, as the architect is the most important man who takes part in the building of a house. The most important improvements of the last twenty-five years are improvements in theory." ${ }^{2 \pi}$ The theory and the jurisprudence here referred to are indigenous, not comparative. "The way to gain a liberal view of your subject is not to read something else, but to get to the bottom of the subject itself.":s Hence, the study of Roman law in a professional curriculum is not advocated."9

In the fifth place, the method of prediction is not merely logical or mathematical:

"The danger of which I speak is not the admission that the principles governing other phenomena also govern the law, but the notion that a given system, ours, for instance, can be worked out like mathematics from some general axioms of conduct...

"This mode of thinking is entirely natural. The training of lawyers is a training in logic. The processes of analogy, discrimination, and deduction are those in which they are most at home. The language of judicial decision is mainly the language of logic. And the logical method and form flatter that longing for certainty and for repose which is in every human mind. But certainty generally is illusion, and repose is not the destiny of man. Behind the logical form lies a judgment as to the relative worth and importance of competing legislative grounds,

\footnotetext{
23 Ibid. 171.

24 Ibid. 170.

25 Ibid. 168.

${ }^{26}$ Ibid. 169.

$2 \pi$ Ibid. 200.

28 Ibid. 197.

29 Ibid. 197ff., 155ff.
} 
often an inarticulate and unconscious judgment, it is true, and yet the very root and nerve of the whole proceeding." 30

This proposition-that law is in substance not logically predictable-is the most important of the applications of the theory of legal history to dogmatic study, since it establishes the further propositions that, after following "the existing body of dogma into its highest generalization by the help of jurisprudence," s1 the methods of dogmatic study are, in the sixth place, "to discover from history how it has come to be what it is; and, finally, so far as you can, to consider the ends which the several rules seek to accomplish, the reasons why those ends are desired, what is given up to gain them, and whether they are worth the price." 32

Thus, the exposition of the canons of dogmatic legal study eventuates, as does the theory of legal history, in stressing the recognition of the "duty of weighing considerations of social advantage." ${ }^{3}$

"I sometimes tell students that the law schools pursue an inspirational combined with a logical method, that is, the postulates are taken for granted upon authority without inquiry into their worth, and then logic is used as the only tool to develop. the results. It is a necessary method for the purpose of tenching dogma. But inasmuch as the real justification of a rule of law, if there be one, is that it helps to bring about a social end which we desire, it is no less necessary that those who make and develop the law should have those ends articulately in their minds." 34

The argument, therefore, concludes in focusing attention upon the third element, the rational or scientific ideal in law. The formulation of the legal process as logical in form but legislative in substance-in other words, essentially in terms of public policy, social ends and the weighing of interests-states the crucial problem of a realistic jurisprudence: How are the factors that condition the law to be ascertained, analyzed and evaluated? The answer is suggestive rather than detailed.

First, rational and scientific study is to be substituted for reliance upon tradition:

"But the present has a right to govern itself so far as it can; and it ought always to be remembered that historic continuity with the past is not a duty, it is only a necessity.

"I hope that the time is coming when this thought will bear fruit. An ideal system of law should draw its postulates and

${ }^{80}$ Ibid. 180, 181.

31 Ibid. 198.

32 Ibid. 198.

33 Ibid. 184.

34 Ibid. 238. 
its legislative justification from science. As it is now, we rely upon tradition, or vague sentiment, or the fact that we never thought of any other way of doing things, as our only warrant for rules which we enforce with as much confidence as if they embodied revealed wisdom." 35

\section{Second,}

"The rational study of law is still to a large extent the study of history. History must be a part of the study, because without it we cannot know the precise scope of rules which it is our business to know. It is a part of the rational study, because it is the first step toward an enlightened scepticism, that is, towards a deliberate reconsideration of the worth of those rules. When you get the dragon out of his cave on to the plain and in the daylight, you can count his teeth and claws, and see just what is his strength. But to get him out is only the first step. The next is either to kill him, or to tame him and make him a useful animal."

Third, the legal science of the future will involve "a substitution of quantitative for qualitative judgments." This for the reason that "it is of the essence of improvement that we should be as accurate as we can" in the measurement of competing social ends." "For the rational study of the law the black-letter man may be the man of the present, but the man of the future is the man of statistics and the master of economics." ss

Thus, both in dogma and in practice, the basis of law is to be scientific. Holmes' view looks beyond formal traditionalism, past even the prevailing standards of professional dogmatic study, to the development of a rational legal science, more empirical and less historical, directed to the more exact measurement of social ends.

"I have had in mind an ultimate dependence upon science because it is finally for science to determine, so far as it can, the relative worth of our different social ends, and, as I have tried to hint, it is our estimate of the proportion between these, now often blind and unconscious, that leads us to insist upon and

35 Ibid. 139. "A body of law is more rational and more civilized when every rule it contains is referred articulately and definitely to an end which it subserves, and when the grounds for desiring that end are stated or are ready to be stated in words.

"At present, in very many cases, if we want to lnow why a rule of law has taken its particular shape, and more or less if we want to lwnow why it exists at all, we go to tradition.... It is revolting to have no better reason for a rule of law than that it so was laid down in the time of Henry IV. It is still more revolting if the grounds upon which it was laid down have vanished long since, and the rule simply persists from blind imitation of the past." Ibid. 186, 187.

36 Ibid. 186-187.

37 Ibid. 231.

38 Ibid. 187. 
to enlarge the sphere of one principle and to allow another gradually to dwindle into atrophy. Very likely it may be that with all the help that statistics and every modern appliance can bring us there never will be a commonwealth in which science is everywhere supreme. But it is an ideal, and without ideals what is life worth? They furnish us our perspectives and open glimpses of the infinite."

No greater praise could be given the conception of legal science, thus fragmentarily sketched, than that, after fifty years, it is still prophetic. The formulation of legal evolution in terms of social ends is of itself a thesis, more profound and universal, more trenchant, than Maine's theorem "from status to contract" or Tarde's law of imitation. And it has a range and vitality which avoids the formalism and lack of perspective in much historical work, such for instance as that of Ames. Its great virtue, however, is to turn historical study upon tradition and thus to suggest the basis for a more rational consideration of legal problems. This lesson, read in the very heyday of the historical school, was a service not fully recognized in its time; it is still to be taken to heart by legal history.

The quality of Holmes' view of legal science is that it is practical. It is no derogation of its validity to point out that this very quality suggests limitations, which, indeed, may very well be fortuitous. It is not to be forgotten that the subject of the lectures on The Common Law was not legal history but the common law system, and that the principal addresses were to the profession-to law students and lawyers, not to scientists. Hence, to avoid misconstruction from the point of view of legal science, positions are not to be taken out of context. Thus, for instance, the practical study of legal history is not without peril in narrow minds; much as such study is needed, much as antiquarian irrelevance is to be eschewed, it needs to be supplemented, as indeed Holmes intimates, by the more remote morphological study of legal institutions and ideas with reference to their social conditions, ends and effects. Again, the definition of legal study as being directed to "the prediction of the incidence of the public force through the instrumentality of the courts," 40 is, as it stands, perhaps appropriate to professional legal study; but for legal science it needs to be defined in terms

${ }^{30}$ Ibid. 242. "I look forward to a time when the part played by history in the explanation of dogma shall be very small, and instead of ingenious research we shall spend our energy on a study of the ends sought to bo attained and the reasons for desiring them. As a step toward that idenl it seems to me that every lawyer ought to seek an understanding of economics. The present divorce between the schools of political economy and law seems to me an evidence of how much progress in philosophical study still remains to be made." Ibid. 195.

40 Ibid. 167. 
of the total social situation, including and beyond the profession. No more, for science, can the basis of prediction be limited to the reports or even the official records. So too, disinterest in foreign legal systems is, because life is short, understandable in professional legal study but not in the university of science. In any event, the limits of legal science are set neither by the profession nor by the common law. Holnes' view of legal science attributes to the practical the penetration of a profound and realistic philosophy of enlightened scepticism. It neither asks nor admits that the lines of the practical should be drawn so straightly or so traditionally as to defeat its own ends.

It would be a fascinating task, one too formidable to be now. essayed, to project against the canvas of Holmes' conception the slow progress of legal science in this country during the past fifty years. Certain points, however, stand out. There is, for instance, the Restatement of the Law, foretold with startling prescience forty-five years since. ${ }^{.1}$ The central canons of objectivity in the study of dogma, of emphasis upon the conscious evaluation of social ends in law, have presaged the most significant developments in legal thought in this country since 1900. These have been the moving ideas of analytical, sociological and functional jurisprudence. Yet even so, the vital inferences await realization. We have been too content with lip service to the thesis that the law is in its grounds legislative and its logic merely formal. As Jerome Frank has sufficiently pointed out, we still pursue the illusion of certainty and seek repose in the logic of tradition. ${ }^{42}$ Dogmatic theory and theoretic dogma yet prevail. And in spite of aspiration, the descriptive basis and the methods of more precise measurement of social ends are, in the main, yet to be ascertained. Thus Holmes' great conception of rational legal science as the basis of law still holds the burden of our hopes. It commands the future, a valid but imperfectly realized ideal.

41 "The law has got to be stated over again; and I venture to say that in fifty years we shall have it in a form of which no man could have dreamed fifty years ago. And now I venture to add my hope and my belice, that, when the day comes which I predict, the Professors of the Harvard Law School will be found to have had a hand in the change not less important than that which Story has had in determining the form of the text-books of the last half-century." Ibid. 42.

42 Frank, Law AND THe MIOdern MIIND (1930). 